\title{
Capnography During Procedural Sedation and Analgesia with Intramuscular Ketamine in Paediatric Patients
}

\author{
Pediyatrik Hastalarda İntramüsküler Ketamin ile Prosedürel Sedasyon ve Analjezi Sırasında \\ Uygulanan Kapnografi
}

\author{
(1) Seyedhossein Seyedhosseini-davarani ${ }^{1}$, (1) Hamideh Akbari ${ }^{1}$, (1) Sepideh Babaniamansour ${ }^{2}$, (1) Ehsan Aliniagerdroudbari ${ }^{3}$, \\ (1) Ehsan Karimialavijeh ${ }^{1}$
}

1 Tehran University of Medical Sciences Faculty of Medicine, Department of Emergency Medicine, Tehran, Iran

2Islamic Azad University Tehran Faculty of Medicine, Department of Emergency Medicine, Tehran, Iran

${ }^{3}$ Shahid Beheshti University of Medical Sciences Faculty of Medicine, Department of Emergency Medicine, Tehran, Iran

\section{Abstract}

Introduction: Capnography is a proven effective tool for procedural sedation and analgesia (PSA); however it is hardly available in developing countries like Iran. This study aimed to discover the frequency of hypoventilation in paediatric patients who received intramuscular (IM) ketamine and evaluate the relationship between end-tidal carbon dioxide $\left(\mathrm{ETCO}_{2}\right)$ changes and other vital signs.

Methods: This was a cross-sectional study conducted in 2019. Paediatric patients (under 14 years old) who underwent PSA with $5 \mathrm{mg} / \mathrm{kg}$ of ketamine given IM participated in this study. $\mathrm{ETCO}_{2}$ was monitored by the mainstream $\mathrm{CO}_{2}$ sensor. Hypoventilation was defined as $\mathrm{ETCO}_{2}$ variation $>10 \mathrm{mmHg}$ from the baseline. Patients $\mathrm{ETCO}_{2}$, oxygen saturation $\left(\mathrm{SPO}_{2}\right)$, pulse rate $(\mathrm{PR})$, respiratory rate (RR) and blood pressure (BP) were continuously monitored and recorded. The specificity and sensitivity of $\mathrm{SPO}_{2}$ for detecting 10 $\mathrm{mmHg}$ change in the $\mathrm{ETCO}_{2}$ level were calculated. In addition, the PR, RR and BP were grouped based on patients' age (1-3 and 3-6 years) and compared between patients who had hypoventilation and others.

Results: A total of 121 patients were enrolled in the study. The mean \pm standard deviation of age was $2.89 \pm 1.48$ years (minimum $=1.2$ and maximum $=5.8$ years). Nineteen $(15.7 \%$ ) patients had $>10$ $\mathrm{mmHg}$ changes in the $\mathrm{ETCO}_{2}$ level. In both age groups, PR and RR had a significant difference between patients with hypoventilation and other patients ( $p=0.001$ in 1-3 years and 0.003 in 3-6 years).

Conclusion: Hypoventilation was frequent among paediatric patients who received IM ketamine; however, it was minimal and required simple airway manoeuvres. Pulse oximetry was not accurate to detect this small amount of hypoventilation. Thus, capnography would provide better monitoring during ketamine PSA.

Keywords: Ketamine, capnography, analgesia, pain management, hypoventilation, conscious sedation, paediatrics

\section{Öz}

Giriş: Kapnografi, prosedürel sedasyon ve analjezi (PSA) için kanıtlanmış etkili bir araçtır; ancak İran gibi gelişmekte olan ülkelerde neredeyse hiç bulunmamaktadır. Bu çalışma, intramüsküler (iM) ketamin alan pediyatrik hastalarda hipoventilasyon sıklığını incelemeyi ve soluk sonu karbondioksit $\left(\mathrm{ETCO}_{2}\right)$ değişiklikleri ile diğer yaşamsal belirtiler arasındaki ilişkiyi değerlendirmeyi amaçladı.

Yöntemler: Bu çalışma, 2019 yılında yapılan kesitsel bir çalışmadır. Bu çalışmaya IM $5 \mathrm{mg} / \mathrm{kg}$ ketamin ile PSA uygulanan pediyatrik hastalar (14 yaş altı) katıldı. $\mathrm{ETCO}_{2}$, ana $\mathrm{CO}_{2}$ sensörü ile izlendi. Hipoventilasyon, varyasyonu başlangıca göre $\mathrm{ETCO}_{2}>10 \mathrm{mmHg}$ olarak tanımlandı. Hastaların $\mathrm{ETCO}_{2}$, oksijen satürasyonu $\left(\mathrm{SPO}_{2}\right)$, nabız hızı (PR), solunum hızı (RR) ve kan basıncı (BP) sürekli izlenerek kaydedildi. $\mathrm{ETCO}_{2}$ seviyesindeki $10 \mathrm{mmHg}$ değişimi tespit etmek için $\mathrm{SPO}_{2}$ 'nin özgüllüğü ve duyarlılığı hesaplandı. Ek olarak, PR, RR ve BP hastaların yaşına (1-3 ve 3-6 yaş) göre gruplandıııldı ve hipoventilasyon olan hastalar ve diğerleri arasında karşılaştııılı.

Bulgular: Çalışmaya toplam 121 hasta kaydedildi. Yaşın ortalama \pm standart sapması $2,89 \pm 1,48$ yıldı (minimum $=1,2$ ve maksimum $=5,8$ yıl). On dokuz $(\% 15,7)$ hastada $\mathrm{ETCO}_{2}$ seviyesinde $>10$ $\mathrm{mmHg}$ değişiklik vardı. Her iki yaş grubunda da PR ve RR açısından hipoventilasyonlu hastalar ile diğer hastalar arasında anlamlı bir fark vardı ( $1-3$ yılda $p=0,001$ ve 3-6 yılda $p=0,003$ ).

Sonuç: iM ketamin alan pediyatrik hastalarda hipoventilasyon sıktı; ancak minimaldi ve basit hava yolu manevraları gerektirdi. Nabız oksimetresi, bu küçük miktardaki hipoventilasyonu saptamak için uygun değildi. Bundan dolayı kapnografi, ketamin PSA sırasında daha iyi izleme sağlayacaktır.

Anahtar Kelimeler: Ketamin, kapnografi, analjezi, ağı yönetimi, hipoventilasyon, bilinçli sedasyon, pediyatri

Yazışma Adresi/Address for Correspondence: Ehsan Karimialavijeh, Tehran University of Medical Sciences Faculty of Medicine, Department of Emergency Medicine, Tehran, Iran E-posta: karimi@sina.tums.ac.ir ORCID ID: orcid.org/0000-0003-0814-9048

Geliş Tarihi/Received: 16.01.2020 Kabul Tarihi/Accepted: 17.04.2020

${ }^{\circ}$ Copyright 2021 by Society of Pediatric Emergency and Intensive Care Medicine

Journal of Pediatric Emergency and Pediatric Intensive Care published by Galenos Yayınevi. 


\section{Introduction}

Reducing pain and anxiety during diagnostic and therapeutic procedures is always of great concern, especially in paediatric patients.

Different pharmacologic agents are used such as midazolam, propofol and ketamine for procedural sedation and analgesia (PSA). A meta-analysis of 8.282 children showed that ketamine was the most effective agent with minimum side effects among dissociative anaesthetics. ${ }^{1-3}$ Ketamine is administered intramuscularly (IM) and intravenously (IV). The prevalence of complications such as laryngospasm and hypopneic hypoventilation, especially in children, is slightly high in IM administration. ${ }^{47}$ Nevertheless, in irritable and agitated children, it is hard to obtain IV access, thus, some physicians use IM ketamine. ${ }^{8}$

Continuous end-tidal carbon dioxide $\left(\mathrm{ETCO}_{2}\right)$ with end-tidal capnography is a reliable method of respiratory monitoring in non-invasive or invasive sedations. It immediately detects hypoventilation, apnoea and respiratory obstruction in early stages..$^{9,10}$

Current guidelines for monitoring and management of paediatric patients recommended the of capnography in all deep sedation. ${ }^{11}$ Capnography is a proven useful tool; however, it is costly. Prices of a portable monitor range from $\$ 3.750$ to $\$ 5.400$ and high-end monitors can cost up to $\$ 35,000 .{ }^{12}$ In developing countries like Iran, it is hardly available in resourcelimited emergency departments (EDs). ${ }^{13}$

Hence, this study used monitoring of vital signs [blood pressure (BP), pulse rate (PR), respiratory rate (RR) and oxygen saturation $\left(\mathrm{SPO}_{2}\right)$ ] plus capnography in paediatric patients undergoing mild to moderate PSA with IM ketamine to evaluate the occurrence of hypoventilation and discover whether other changes can be detected via vital signs in $\mathrm{ETCO}_{2}$ during PSA with IM ketamine or not.

\section{Materials and Methods}

\section{Study design}

This was a cross-sectional study conducted in 2019 in an ED of a university-affiliated Tertiary Referral Hospital in Tehran, Iran. This study was approved by the Ethics Committee of the Tehran University of Medical Sciences (approval no: 1398.592, approval date: 2019-10-23). Informed consent was obtained from all guardians of paediatric patients. Patients were monitored using a portable cardiac monitoring device (ZOLL ${ }^{\circledR}$ R Series ${ }^{\circledR}$ monitor/defibrillator), which was equipped with a $\mathrm{CO}_{2}$ sensor, pulse oximetry and electrocardiogram monitoring electrodes. ETCO 2 was monitored by a mainstream $\mathrm{CO}_{2}$ sensor through a face mask, and oxygen ( $\left.5 \mathrm{~L} / \mathrm{min}\right)$ was delivered. PSA regiments were chosen based on the decision of the treating emergency medicine (EM) physician. The research team was informed when the PSA was performed with ketamine (IM). Bradypnea can be detected by RR alterations, thus, this study aimed to evaluate the frequency of hypopeneic hypoventilation defined as $\mathrm{ETCO}_{2}$ variation $>10$ $\mathrm{mmHg}$ from the baseline. ${ }^{14}$

\section{Participants}

All paediatric patients (under 14 years old) who underwent PSA with $5 \mathrm{mg} / \mathrm{kg}$ of IM ketamine ${ }^{6}$ were included in the study by convenient sampling. Exclusion criteria includes PSA with other drugs based on the judgement of the treating EM (in case of the presence of contraindications including allergy history to ketamine, history of asthma and reactive airway diseases, age under three months, suspicion of high intracranial pressure and any coagulation disorder dose does not permit IM injection) and parental refusal.

\section{Data collection}

During the PSA, a nurse investigator and two EM physicians (not involved in the patient care) continuously monitored and recorded patients $\mathrm{ETCO}_{2}, \mathrm{SPO}_{2}, \mathrm{PR}$ and $\mathrm{RR}$. BP was measured every 5 mins. In the event of hypoxia $\left(\mathrm{O}_{2}\right.$ sat $\left.<90 \%\right)$, treating physicians and nurses made necessary interventions by increasing the oxygen flow, airway manoeuvres and bag-mask ventilation. Vital signs were grouped for each age group (0-1, $1-3$ and 3-6 years). ${ }^{15}$

\section{Sample size}

Considering the probability of $15 \%$ for the hypoventilation in PSA by ketamine ${ }^{14}$ and the 0.5 accuracy, the calculated sample size was 100 patients.

\section{Statistical Analysis}

Statistical Package for the Social Sciences (Version 22.0, SPSS Inc., Chicago, IL, USA) was used to analyse the data. Kolmogorov-Smirnov test was used to assess the normality assumption for continuous variables. The chi-square test was used to analyse qualitative data. The Mann-Whitney $U$ test was used to compare the vital signs between patients with and without hypoventilation. The specificity and sensitivity of $\mathrm{SPO}_{2}$ for detecting $10 \mathrm{mmHg}$ change in the $\mathrm{ETCO}_{2}$ level were calculated. A p-value of $<0.05$ was considered as a level of significance.

\section{Results}

A total of 121 patients were enrolled in the study. The mean \pm standard deviation (SD) of age was 2.89 \pm 1.48 (minimum $=1.2$ and maximum $=5.8)$, and $74(61.2 \%)$ were male. $A$ hundred eleven $(91.73 \%)$ patients underwent PSA for laceration 
repair and 8 (8.26\%) experienced PSA for fracture reduction. Nineteen $(15.7 \%)$ patients had $>10 \mathrm{mmHg}$ changes in their $\mathrm{ETCO}_{2}$ levels. All patients who had hypoventilation were managed by airway manoeuvres, including head-tilt, chin-lift, open mouth and increasing the oxygen flow up to $10 \mathrm{~L} / \mathrm{min}$.

Among vital signs, PR and RR had a significant difference among patients with respiratory depression (Table 1).

The drop in mean $\mathrm{ETCO}_{2}$ at each time point was statistically significant ( $p=0.005,0.001$ and 0.04 , at 5, 15 and 30 minutes, respectively); however, it was not clinically important because mean $\mathrm{ETCO}_{2}$ changes at each point were not $>10 \mathrm{mmHg}$ (Figure 1).

The mean $\pm \mathrm{SD}$ of $\mathrm{SPO}_{2}$ was not statistically different between patients with and without hypoventilation $(99.48 \pm 0.78$ and $99.56 \pm 0.9$, respectively, $p=0.7$ ). The sensitivity and specificity of $\mathrm{SPO}_{2}$ in detecting $10 \mathrm{mmHg}$ changes in $\mathrm{ETCO}_{2}$ were $63.2 \%$ and $29.4 \%$, respectively.

\section{Discussion}

Our study investigated the hypoventilation in paediatric patients who underwent PSA with IM ketamine. Results

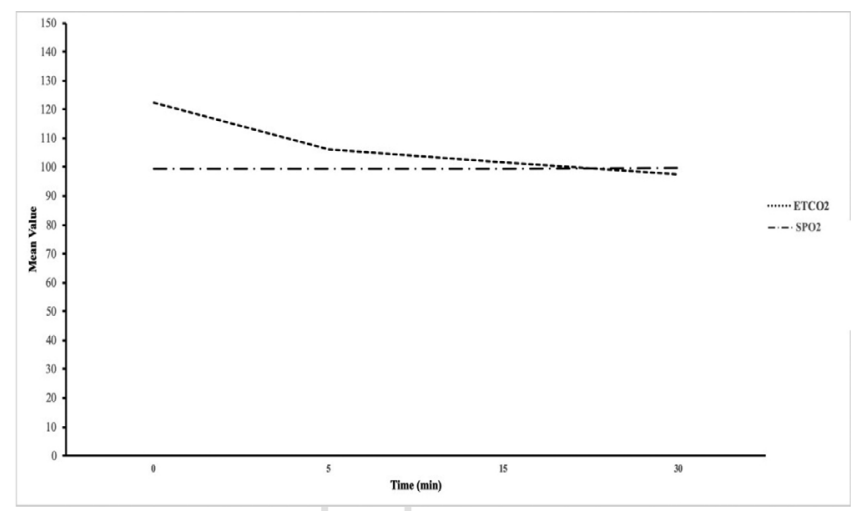

Figure 1. The mean change of $\mathrm{ETCO}_{2}$ and $\mathrm{SPO}_{2}$ over time $\mathrm{ETCO}_{2}$ : End-tidal carbon dioxide, $\mathrm{SPO}_{2}$ : Oxygen saturation showed that 19 (15.7\%) of 121 patients had $>10 \mathrm{mmHg}$ changes in $\mathrm{ETCO}_{2}$ levels. This rate is higher than that of previous reports on side effects of ketamine. Melendez and Bachur ${ }^{16}$ reported $2.4 \%$ of adverse respiratory events (apnoea, $\mathrm{SPO}_{2}$ $<93 \%$, hypoventilation and laryngospasm), and in the study of Green et al. ${ }^{1}$ on 8.282 children undergoing PSA with IV ketamine, incidence of airway and respiratory adverse events was $3.9 \%$.

Higher frequency of adverse respiratory events may attribute to IM administration of ketamine in our study.

Apnoea, laryngospasm or airway obstruction were not seen among participants in the present study. All patients with hypoventilation were managed with simple interventions such as increasing the oxygen flow and primary airway manoeuvres (stimulation, head-tilt, chin-lift, jaw thrust and increasing the oxygen flow). None required intubation or bagmask ventilation.

Based on previous studies, in many cases, hypoventilation is transient and spontaneously resolves as the drug effect wears off.

Nevertheless, some specialists who used capnography in patients undergoing PSA argued that during the PSA, it is more likely for patients to be subjected to bag-valve-mask ventilation to resolve hypoxia. As a result, the risk of aspiration would increase due to the insufflation of the patient's stomach. Nevertheless, the benefit of capnography during PSA is noticeable, and the latest guideline for monitoring and management of paediatric patients recommended capnography in deep sedation. ${ }^{11}$

During the procedure, any vomiting among patients was not observed. This finding is in contrast with the findings from the study of Momeni et al. ${ }^{4}$ They reported that nausea and vomiting were the only side effects in children undergoing PSA with ketamine. Of note; they did not use capnography in their study to detect hypoxia in their patients.

PSA with ketamine in recommended doses usually provides mild to moderate sedation, and in our study, the

\section{Table 1. Comparison of vital signs between patients with and without hypoventilation}

\begin{tabular}{|c|c|c|c|}
\hline Age group & $\begin{array}{l}\text { With } \\
\text { hypoventilation } \\
n=19\end{array}$ & $\begin{array}{l}\text { Without hypoventilation } \\
\mathrm{n}=102\end{array}$ & $\mathbf{p}$ \\
\hline $\begin{array}{l}\text { 1-3 (years, N\%) } \\
\text { PR (per min, median, IQR) } \\
\text { RR (per min median, IQR) } \\
\text { SBP (mmHg, median, IQR) } \\
\text { DBP (mmHg, median, IQR) }\end{array}$ & $\begin{array}{l}12(63.1) \\
102.62(35.87) \\
27.53(5.33) \\
91.42(4.18) \\
48.01(5.04)\end{array}$ & $\begin{array}{l}65(63.7) \\
121.53(12.96) \\
30.7(1.53) \\
91.3(4.64) \\
49.84(7.87)\end{array}$ & $\begin{array}{l}0.9 \\
0.001 \\
0.001 \\
0.19 \\
0.2\end{array}$ \\
\hline $\begin{array}{l}\text { 3-6 (years, N\%) } \\
\text { PR (per min, median, IQR) } \\
\text { RR (per min median, IQR) } \\
\text { SBP (mmHg, median, IQR) } \\
\text { DBP (mmHg, median, IQR) }\end{array}$ & $\begin{array}{l}7(36.8) \\
105.4(20.12) \\
26.32(4.67) \\
93.23(5.1) \\
50.2(6.18)\end{array}$ & $\begin{array}{l}37(36.2) \\
119.34(10.89) \\
28.8(2.1) \\
93.7(4.9) \\
51.4(5.82)\end{array}$ & $\begin{array}{l}0.9 \\
0.003 \\
0.003 \\
0.3 \\
0.2\end{array}$ \\
\hline
\end{tabular}


hypoventilation was minimal, possible detrimental effects of this mild hypoxia on the physiologic function of the end organs, most importantly the developing brain, is still controversial. ${ }^{17,18}$

\section{Study Limitations}

This study has limitations. The number of participants was limited because it was conducted in an ED setting, and patients received different regimens for PSA based on the discretion of the treating physicians. In addition, the homogeneity of patients in this study may increase the bias of results. Most of patients were toddlers, and we did not evaluate neonates, infants or older paediatric patients. Moreover, we did not evaluate bradypeneic hypoventilation; therefore, our results did not show any chronological relationship between the $\mathrm{ETCO}_{2}$ and $\mathrm{SPO}_{2}$.

\section{Conclusion}

During the PSA with IM ketamine, hypoventilation was minimal but frequent. Pulse oximetry was not accurate to detect small amounts of hypoventilation, thus, capnography seems to provide better monitoring for pediatric undergoing PSA with IM ketamine.

\section{Ethics}

Ethics Committee Approval: This study was approved by the Ethics Committee of the Tehran University of Medical Sciences (approval no: 1398.592, approval date: 2019-10-23).

Informed Consent: Informed consent was obtained from all guardians of paediatric patients.

Peer-review: Internally peer-reviewed.

\section{Authorship Contributions}

Surgical and Medical Practices: S.B., Concept: S.S.D., Design: S.S.D., Analysis or Interpretation: H.A., Literature Search: E.A., E.K., Writing: E.A.

Conflict of Interest: No conflict of interest was declared by the authors.

Financial Disclosure: The authors declared that this study received no financial support.

\section{References}

1. Green SM, Roback MG, Krauss B, Brown L, McGlone RG, et al. Predictors of airway and respiratory adverse events with ketamine sedation in the emergency department: an individual-patient data meta-analysis of 8,282 children. Ann Emerg Med. 2009;54:158-68.

2. Aydin Erden I, Gulsun Pamuk A, Akinci SB, Koseoglu A, Aypar U. Comparison of propofol-fentanyl with propofol-fentanyl-ketamine combination in pediatric patients undergoing interventional radiology procedures. Paediatr Anaesth. 2009;19:500-6.

3. Alletag MJ, Auerbach MA, Baum CR. Ketamine, propofol, and ketofol use for pediatric sedation. Pediatr Emerg Care. 2012;28:1391-5.

4. Momeni M, Esfandbod M, Saeedi M, Farnia M, Basirani R, et al. Comparison of the effect of intravenous ketamine and intramuscular ketamine for orthopedic procedures in children's sedation. Int J Crit IIIn Inj Sci. 2014;4:191-4.

5. Chiaretti A, Ruggiero A, Barone G, Antonelli A, Lazzareschi I, et al. Propofol/alfentanil and propofol/ketamine procedural sedation in children with acute lymphoblastic leukaemia: safety, efficacy and their correlation with pain neuromediator expression. Eur J Cancer Care (Engl). 2010;19:212-20.

6. Yee R, Chay PL, Tham LP. Safety and effectiveness of intramuscular ketamine sedation in the management of children with oro-dental trauma in a paediatric emergency department. Dent Traumatol. 2020;36:19-24.

7. Shah A, Mosdossy G, McLeod S, Lehnhardt K, Peddle M, et al. A blinded, randomized controlled trial to evaluate ketamine/propofol versus ketamine alone for procedural sedation in children. Ann Emerg Med. 2011;57:425-33.

8. Campbell SG, Magee KD, Zed PJ, Froese P, Etsell G, et al. End-tidal capnometry during emergency department procedural sedation and analgesia: a randomized, controlled study. World J Emerg Med. 2016;7:13-8.

9. Yosefy C, Hay E, Nasri Y, Magen E, Reisin L. End tidal carbon dioxide as a predictor of the arterial PCO2 in the emergency department setting. Emerg Med J. 2004;21:557-9.

10. Gallagher JJ. Capnography Monitoring During Procedural Sedation and Analgesia. AACN Adv Crit Care. 2018;29:405-14.

11. Coté CJ, Wilson S; AMERICAN ACADEMY OF PEDIATRICS; AMERICAN ACADEMY OF PEDIATRIC DENTISTRY. Guidelines for Monitoring and Management of Pediatric Patients Before, During, and After Sedation for Diagnostic and Therapeutic Procedures. Pediatrics. 2019;143:20191000.

12. Saunders R, Davis JA, Kranke P, Weissbrod R, Whitaker DK, et al. Clinical and economic burden of procedural sedation-related adverse events and their outcomes: analysis from five countries. Ther Clin Risk Manag. 2018;14:393-401.

13. Jooste R, Roberts F, Mndolo S, Mabedi D, Chikumbanje S, et al. Global Capnography Project (GCAP): implementation of capnography in Malawi - an international anaesthesia quality improvement project. Anaesthesia. 2019;74:158-66.

14. Langhan ML, Chen L, Marshall C, Santucci KA. Detection of hypoventilation by capnography and its association with hypoxia in children undergoing sedation with ketamine. Pediatr Emerg Care. 2011;27:394-7.

15. Part 10: Pediatric Advanced Life Support. Circulation. 2000;102:I-291-I-342

16. Melendez E, Bachur R. Serious adverse events during procedural sedation with ketamine. Pediatr Emerg Care. 2009;25:325-8.

17. Zhang J, Chen J, Fan C, Li J, Lin J, et al. Alteration of Spontaneous Brain Activity After Hypoxia-Reoxygenation: A Resting-State fMRI Study. High Alt Med Biol. 2017;18:20-6.

18. Nyakas C, Buwalda B, Luiten PG. Hypoxia and brain development. Prog Neurobiol. 1996;49:1-51. 